African Crop Science Journal by African Crop Science Society is licensed under a Creative Commons Attribution 3.0 Uganda License. Based on a work at www.ajol.info/ and www.bioline.org.br/cs DOI: https://dx.doi.org/10.4314/acsj.v26i4.5

\title{
LEVERAGING BIOLOGICAL NITROGEN FIXATION AND SOYBEAN YIELD BY PLANTING DURATION UNDER VARYING ONSET OF RAINY SEASONS IN UGANDA
}

\author{
J.B. TUMUHAIRWE, J. GOLOOBA, A. AMODING and L.N. MULUMBA
}

School of Agricultural Science, Department of Agricultural Production, Makerere University, P. O. Box 7062, Kampala, Uganda

Corresponding author: jbtumuhairwe@ caes.mak.ac.ug

(Received 24 April, 2018; accepted 24 October, 2018)

\begin{abstract}
Rainfall distribution and onset of rainy seasons, both of which are key determinants of the decision to plant most annual crops in sub-Saharan Africa (SSA), are increasingly difficult to predict due to climate change. Consequently, planting schedules affect both crops and vital natural systems such as biological nitrogen fixation in legumes. The objective of this study was to establish the optimum planting duration for soybean (Glycine max L.), from the onset of the rainy season, in the context of nodulation and grain yield, and diversity of rhizobia in rhizosphere soil and nodules. A field experiment was set up with treatments, Bradyrhizobia inoculated and non- inoculated soybean variety Maksoy3N planted at four dates; 0, 10, 20 and 30 days from the onset of rain season. Diversity of rhizobia in the rhizosphere soil and nodules were fingerprinted using Single Strand Conformation Polymorphism (SSCP) method. Inoculation significantly $(\mathrm{P}<0.05)$ increased the number but not effectiveness of nodules and grain yield; which was attributed to presence of native strains in the soil. Planting after 10 days following the onset of a rainy season significantly $(\mathrm{P}<0.05)$ reduced grain yields and total yield loss was realised when seasonal cumulative rainfall was about $500 \mathrm{~mm}$. Planting after 20 days from onset of rainy season significantly $(\mathrm{P}<0.05)$ reduced the total number of nodules. A total of 8 and 12 clusters of bacteria from the soil and nodules at $5 \%$ dissimilarity, respectively, were recorded. The Bradyrhizobia species consisted of B. japonicum, B. japonicum (USDA 6), B. elkanii, B. liaoningense, B. canariense, and B. yuanmingense.
\end{abstract}

Key Words: Climate change, inoculation, nodulation, rhizobia

\section{RÉSUMÉ}

La distribution des pluies et le début des saisons pluvieuses, à la fois sont des déterminants clés dans la décision de semis de la plupart des cultures annuelles en Afrique sub-sahariennes (SSA), sont progressivement difficiles à prédire à cause des changements climatiques. EN conséquence, le calendrier agricole affecte à la fois les cultures et les systèmes naturels vitaux tels que la fixation biologique d'azote dans les légumineuses. L'objectif de cette étude était d'établir la durée optimale de culture pour le soja (Glycine max L.), au début de la saison pluvieuse, dans le contexte de la nodulation et du rendement en grain et la diversité en rhizobia dans la rhizosphère du sol et les nodules. Une expérimentation au champ a été mise en place avec les traitements, la variété Maksoy3N inoculée et non inoculée avec Bradyrhizobia semée en quatre dates ; 0, 10, 20 et 30 jours depuis le début de la saison. Les empreintes digitales de la diversité de rhizobia dans la rhizosphère du sol et les nodules ont été évaluées en utilisant la méthode de recherche du polymorphisme de conformation (SSCP). L'inoculation a significativement $(\mathrm{P}<0,05)$ fait augmenter le nombre mais non n'effectivité des nodules et le rendement en grain ; 
qui est attribuée à la présence des souches natives au sol. Le semis 10 jours après le début de la saison pluvieuse a significativement réduit $(\mathrm{P}<0,05)$ réduit les rendements en grain et la perte totale du rendement a été observée lorsque la pluie cumulative saisonnière a été environ $500 \mathrm{~mm}$. Le semis 20 jours après le début de la saison pluvieuse a significativement $(\mathrm{P}<0.05)$ réduit le nombre total de nodules. Un total de 8 et 12 groupes de bactéries du sol et des nodules à une dissimilarité de 5\%, respectivement ont été observés. Les espèces de Bradyrhizobia sont consisté B. japonicum, B. japonicum (USDA 6), B. elkanii, B. liaoningense, B. canariense, et B. yuanmingense.

Mots Clés: Changement climatique, inoculation, nodulation, rhizobia

\section{INTRODUCTION}

Climate change is responsible for significant fluctuations in rainfall and temperature, thus affecting agricultural production under rainfed systems. The onset of rainy seasons, which is the primary determinant of planting time is increasingly affected. Adjusting planting dates has become an important agronomic phenomenon for improving crop yields and overall adaptation to climate change (Hu et al., 2017). Rainfall distribution and onset of rainy seasons are key determinants of the decision when farmers plant in sub-Saharan Africa (SSA). These key factors are increasingly difficult to predict amidst the challenges of climate variability, particularly to leverage biologically fixed $\mathrm{N}$ by legume crops such as soybean (Glycine max L. Merr).

Soybean is cultivated worldwide and fixes the largest quantity of nitrogen biologically among legumes in agro-ecosystems (Sanginga et al., 2002). Up to $16 \mathrm{Tg} \mathrm{N}$ per year has been attributed to BNF systems, thus contributing up to $77 \%$ of global crop legume BNF (Herridge et al., 2008). Soybean fixes nitrogen through symbiotic association with Bradyrhizobium strains. Several studies have reported increased BNF following Bradyrhizobium japonicum (USDA 110) inoculation on soybean in SSA (Sanginga et al., 1996; Thuita et al., 2012; Gyogluu et al., 2016; van Heerwaarden et al., 2018).

There is increasing concern that climate change will reduce benefits of plant growth promoting rhizobacteria such as biological nitrogen fixation (Thomas et al., 2006). The increase in temperatures and reduction in rainfall due to climate change and are predicted to affect the complex legume crop management, especially nitrogen nutrition (Vadez et al., 2012); perhaps by impacting the symbiotic association between rhizobia and leguminous plants. Most farmers in SSA use planting date as an adaptation measure to climate variability (Mapfumo et al., 2013). Indeed, the feasible strategies for adjusting to climate change depicted by rainfall variability that are within reach of the resource poor, include rhizobia inoculation, planting varieties that are resilient to water stress and timely planting to reduce on the impact of increased drought occurrence.

Simulating the effect of climate change on soybean yield using Regional Circulation Models predicted a decline in grain yield following early planting immediately at the onset of rainy season (Eulenstein et al., 2016). Relatedly, Fu et al. (2016), predicted a reduction in soybean production attributed to climate warming and proposed late planting, and breeding for thermal tolerance during reproductive stages as management and mitigation options. Earlier, rhizobia were considered competitive bacteria that could persist at high populations in the soil (Sanginga et al., 1996; Giller, 2001). However, a decrease in the population of rhizobia by 10 to $20 \%$ in soil, even within the rainy season, has been reported, especially for slow growing bacteria (Kumar et al., 2017); moreover Bradyrhizobia belong to this group of bacteria. The objective of this study was to establish the optimum planting date for inoculated soybean to suite small scale farming systems under varied onset of rainy seasons in Uganda. 
MATERIALS AND METHODS

Experimental site characteristics. The study was conducted on-farm in Lira district, in northern Uganda. The area is about $1200 \mathrm{~m}$ above sea level and the soils are classified as Ferralsol on sandy sediment. The area receives $1200-1600 \mathrm{~mm}$ of rainfall per annum, and temperatures minimum and maximum of 22.5 and $25.5^{\circ} \mathrm{C}$, respectively. The rainfall pattern is bimodal with the long rainfall peaking between April - May, and the short one peaking in September - October.
In this study, the average rainfall received varied by season both in quantity and distribution within the growing season (Fig. 1). The second season experiment (2011A) received the highest total amount of rainfall $(768.0 \mathrm{~mm})$; followed by the first season (2010 B) with $728.9 \mathrm{~mm}$ and least rains $(536.1 \mathrm{~mm})$ received in the third season (2011B).

The experiment was conducted for three seasons, namely from the second rainy season of 2010 (2010B) then 2011A and 2011B. Composite soil samples were collected from four experimental sites per season and analysed


Figure 1. Rainfall received in Lira during the experiment to revelage biological nitrogen fixation and soybean yield by planting date in northern Uganda. $\mathrm{A}=$ Short rains season and $\mathrm{B}=$ Long rains season. 
for selected chemical properties and soil texture (Table 1), following standard procedures (Okalebo et al., 2002). The results revealed that the soils were acidic, and low in organic matter, total nitrogen, available phosphorus and exchangeable bases (Table 1). All the 12 sites had a Sandy Clay Loam textural class. The study fields selected were ploughed and harrowed, and marked into plots of $6 \mathrm{~m} \mathrm{x}$ $5 \mathrm{~m}$, separated by $2 \mathrm{~m}$ alleys. New fields were selected for each season to avoid residual effects of Bradyrhizobia japonicun inoculation on soybean from the previous season.

Treatments and design. Treatments included four planting dates at 10 days interval $(0,10$, 20 and 30), from the onset of the rainy season, for a duration of 30 days, with and without inoculation with Bradyrhizobia japonicum inoculation on soybean. The actual planting dates for season 2010 were: 18 and $28^{\text {th }}$ August and 7 and $17^{\text {th }}$ September. For season 2011A the planting dates were $28^{\text {th }}$ April and $9^{\text {th }}, 19^{\text {th }}$ and $29^{\text {th }}$ May. Planting dates for season 2011B were $29^{\text {th }}$ August and $10^{\text {th }}, 20^{\text {th }}$ and $30^{\text {th }}$ September.

Treatments were laid out in a randomised complete block design, with four replicates. The different farmer sites per season were the replicates. Each plot received basal application of phosphorus at a rate of $15 \mathrm{~kg} \mathrm{P} \mathrm{ha}^{-1}$, using Single Super Phosphate $\left(18 \% \mathrm{P}_{2} \mathrm{O}_{5}\right)$, all applied at planting. Quality certified seed of soybean variety Maksoy $3 \mathrm{~N}$ was obtained from Makerere University Agricultural Research Institute. The inoculum Makbiofixer was also obtained from Department of Agricultural Production, Makerere University, and consisted of Bradyrhizobia japoniucum Strain USDA 110 at a population of $10^{9}$ cells per gramme.

The inoculum was applied following standard procedures for seed inoculation (FAO, 1984). Non-inoculated seeds were always planted before the inoculated ones to avoid cross contamination. Two seeds were planted per hill at spacing of $50 \mathrm{~cm}$ between rows and $25 \mathrm{~cm}$ within rows. Weeding was manually




done using a hand hoe, whenever weeds appeared, to maintain weed-free experiment.

Data collection. Data were collected on nodulation, diversity of rhizosphere and nodule resident Bradyrhizobia, and soybean yield. Nodulation assessment was done in the $8^{\text {th }}$ week, counted from actual planting dates. Eight plants were randomly selected from the second row but skipping the exterior first two plants. The plants were dug out with a hoe to recover rhizosphere soil and nodules. Rhizosphere soil sample was composed of the residue soil around the roots after removing the bulk soil.

For diversity of Bradyrhizobia in the rhizosphere, a composite soil sample was obtained from the root surface of the sampled plants. The soil samples were stored in a cool box, while in the field; and at $-26^{\circ} \mathrm{C}$ in the laboratory until when used for DNA extraction. All nodules on each sampled plant were severed from the roots and counted. Thereafter, five nodules from each plant were randomly selected and stored in glass vials with silica gel; and were later used for DNA extraction to identify rhizobia community in nodules using Polymerase chain reaction (PCR); followed by Single Strand Conformation Polymorphism (SSCP). Similar procedures were followed to identify the community in the rhizosphere soil (Dohrmann and Tebbe, 2005; Smalla et al., 2007). The remaining nodules were dissected cross-sectionally and observed for presence of leghaemoglobin (pinkish pigment) as a proxy indicator of effective nitrogen fixing nodules (Hardarson and Atkins, 2003; Sainz et al., 2016). Any nodule with a different inside colour was considered not effective for biological nitrogen fixation.

One week after full pod maturity (when $95 \%$ of the pods had changed to brown colour), three inner rows of soybean in each plot were harvested for grain yield assessment. The outer two rows on either side were left out as guard rows, giving a net harvested area of $6 \mathrm{~m}^{2}$ after leaving out $1 \mathrm{~m}$ on either width and length side of the plot. The harvested soybean was sun-dried for 5 to 7 days when they could easily be threshed, and grain yield was determined at $12-14 \%$ moisture content measured with a portable moisture analyser for grain and seed (Farmpro).

Molecular analyses on rhizosphere soil and nodule samples were conducted at University of Technology, Graz (TUG) in Austria. Genomic DNA was extracted from soil and nodules using the Fast DNA Spin kit for soil (MP Biomedicals, Solon, USA), following the manufacturer's protocol. DNA was amplified using forward primer Alf28f (3'ARCGAAC GCTGGCGGCA5') and reverse primer 1512uR (5'ACGGHTACCTTGT TACGACT T3') targeting the 16S rDNA gene. The PCR was performed using a reaction mix of $60 \mu \mathrm{M}$, containing 1 x Taq \&Go PCR Mastermix (MP Biochemicals, Eschwege, Germany), $3 \mathrm{mM}$ $\mathrm{MgCl} 2,0.5 \mu \mathrm{M}$ of each of the primers and 1 $\mu \mathrm{M}$ of genomic DNA. The PCR conditions were initial denaturing at $95^{\circ} \mathrm{C}$ for 5 minutes; followed by 25 cycles of $95^{\circ} \mathrm{C}$ for $30 \mathrm{~s}, 55^{\circ} \mathrm{C}$ for $20 \mathrm{~s}, 72{ }^{\circ} \mathrm{C}$ for $30 \mathrm{~s}$ and final annealing at $72^{\circ} \mathrm{C}$ for 10 minutes. The integrity of the PCR product was first checked on $1.5 \%$ agarose gel before performing SSCP.

The SSCP was performed on $12 \%$ acrylamide gel to fingerprint the alphaproteobacteria community in the rhizosphere soil and nodule. Band, on the SSCP gel were excised, cleaned using QIA Quick gel extraction kit, following the manufacture's protocol. Purified DNA was sequenced to confirm the Bradyrhizobia strains existing in the rhizosphere soil and nodules.

Statistical analysis. Nodule counts and grain yield data were subjected to analysis of variance using GenStat statistical package. Data for nodule counts were normalised by logarithm transformation before analysis of variance. Means were compared using the Least Significant Difference at 5\% level of significance. SSCP profiles were subjected to cluster analysis at 5\% dissimilarity. The sequences were subjected to Basic Local 
Alignment Search Tool (BLAST) for identification and were aligned to a phylogenetic tree using near neighboring approach.

\section{RESULTS AND DISCUSSION}

Nodulation and grain yield. Varying planting dates significantly $(\mathrm{P}<0.05)$ affected the number of nodules on soybean plant roots (Fig. 2 ). The number of nodules increased from the onset of rains, through 20 days after planting, irrespective of inoculation. Thereafter, the numbers decreased when soybean was planted on the $30^{\text {th }}$ day from onset of rains, irrespective inoculation across all seasons (Table 2). Therefore, soybean did not benefit from the interaction of planting time and inoculation, which indicates that both the native and introduced $B$. japonium strains responded similarly to moisture.

This study has demonstrated that the number of nodules is reduced by about 12 to $40 \%$ when soybean was planted after 10 and 20 days, respectively, from the onset of rainy season, which can significantly reduce biologically fixed nitrogen. This was mainly attributed to moisture stress on the plant as the rains decrease, which reduces plantmicrobe interaction as earlier reported by
Keyser and Li (1992). It is evident from this study that even when farmers had a planting period of 30 days, the maximum date for planting inoculated soybean was 20 days from the onset of rainy season. It was expected that early planting at onset of rains (0 days) would increase nodulation, but it was to the contrary and no explanation can be derived from the study. However, it was evident from the study that the peak number of nodules occurred when planting was done between 10 and 20 days from the onset of rain season (Fig. 2 and Table 2). This was attributed to rainfall (Fig. 1), which increases moisture in the soil after the on-set of season. Prior to this, it was a dry season and soil moisture levels could have been low, thus restraining growth and activity of both the native and applied Bradyrhizobia.

The inoculated treatments had more nodules than the non-inoculated treatments at all planting dates (Fig. 2), indicating a positive response to inoculation, which can be attributed to a low population of native $B$. japonium of about $103 \mathrm{CFU} \mathrm{g}^{-1}$ in soil (Table 1). The inoculation effect increased with planting dates up to 20 days. Bradyrhizobia species, like most soil microorganisms, require moisture for growth and activity, thus nodulation and $\mathrm{N}$-fixation were negatively

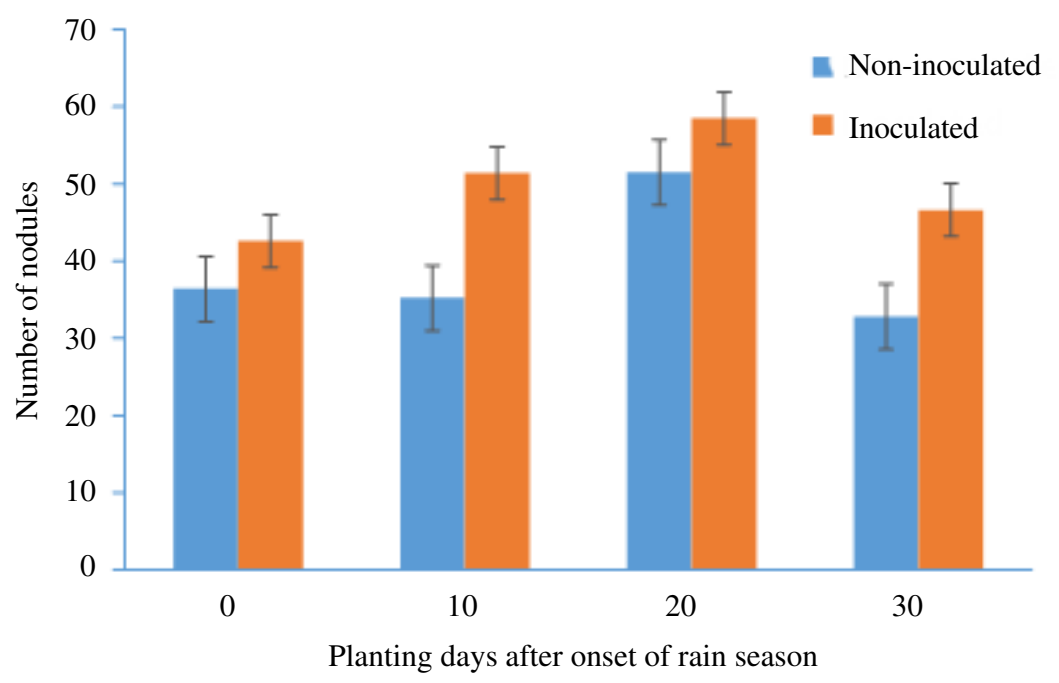

Figure 2. Number of nodules on soybean at different planting dates in northern Uganda. 
affected by low rainfall received between 31 and 40 days (Fig. 1), which coincided with the vegetative stage of the crop. It is clear from this study that planting soybean within 10 20 days from the onset of rains realised the peak number of nodules with and without inoculation (Table 2 . The difference in nodule number between inoculated and noninoculated treatment can be attributed to increased population of effective $B$. japonium on the seeds following inoculation. Apparently, the soils in the study sites contained native Bradyrhizobia strains averaging $3.0 \times 10^{3} \mathrm{CFU}$ $\mathrm{g}^{-1}$ (Table 1), accounting for nodulation even without inoculation (Table 2). The native Bradyrhizobia strains were infective indicated by the effective nodule reaching $100 \%$ in
Season 2011B (Table 3). However, the population of native Bradyrhizobia strains was low (Table 1) necessitating inoculation depicted by low number of nodules without inoculation. The population of native Bradyrhizobia strains could be attributed to previous planting of soybean in the area. Earlier studies have shown that rhizobia population can be maintained in the soil as long as the host legume is included in the cropping sequence (Giller, 2001; Kumar et al., 2017).

Late planting dates (beyond 20 days from the onset of rains) significantly $(\mathrm{P}<0.05)$ and consistently decreased soybean grain yield (Tables 4 and 5). Most grain yield was realised when soybean was planted at the onset of rains, with and without inoculation (Table

TABLE 2. Number of nodules in soybean at 56 days after planting following different planting dates and inoculation in northern Uganda

\begin{tabular}{|c|c|c|c|c|c|c|}
\hline \multirow[b]{2}{*}{ Planting dates } & \multicolumn{2}{|c|}{ Season 2010B } & \multicolumn{2}{|c|}{ Season 2011A } & \multicolumn{2}{|c|}{ Season 2011B } \\
\hline & Non $^{1}$ & Inoculated & Non & Inoculated & Non & Inoculated \\
\hline 0 & 25.0 & 17.8 & 59.7 & 78.1 & 21.7 & 29.7 \\
\hline 10 & 22.8 & 30.5 & 52.9 & 69.4 & 29.3 & 56.7 \\
\hline 20 & 35.0 & 29.5 & 61.0 & 77.0 & 62.0 & 73.7 \\
\hline 30 & 21.0 & 21.5 & 48.6 & 65.4 & 28.7 & 56.3 \\
\hline \multirow{2}{*}{$\operatorname{LSD}_{(0.05)} \begin{array}{l}\text { Planting date } \\
\text { Inoculation }\end{array}$} & \multicolumn{2}{|c|}{9.76} & \multicolumn{2}{|c|}{8.69} & \multicolumn{2}{|c|}{3.82} \\
\hline & \multicolumn{2}{|c|}{6.90} & \multicolumn{2}{|c|}{6.15} & \multicolumn{2}{|c|}{2.70} \\
\hline
\end{tabular}

${ }^{1}$ Non $=$ Non-inoculated

TABLE 3. Effective nodules (\%) in soybean at 56 days after planting following varied planting and inoculation in northern Uganda

\begin{tabular}{|c|c|c|c|c|c|c|}
\hline \multirow[b]{2}{*}{ Planting dates } & \multicolumn{2}{|c|}{ Season 2010B } & \multicolumn{2}{|c|}{ Season 2011A } & \multicolumn{2}{|c|}{ Season 2011B } \\
\hline & Non $^{1}$ & Inoculated & Non & Inoculated & Non & Inoculated \\
\hline 0 & 69.8 & 72.8 & 99.3 & 99.0 & 86.3 & 92.7 \\
\hline 10 & 66.8 & 73.8 & 96.8 & 98.5 & 100.0 & 94.3 \\
\hline 20 & 88.8 & 75.8 & 89.8 & 94.8 & 100.0 & 97.7 \\
\hline 30 & 56.5 & 65.0 & 89.3 & 93.3 & 78.3 & 86.7 \\
\hline \multirow{2}{*}{$\begin{array}{ll}\text { LSD }_{(0.05)} & \text { Planting date } \\
\text { Inoculation }\end{array}$} & \multicolumn{2}{|c|}{19.53} & \multicolumn{2}{|c|}{3.69} & \multicolumn{2}{|c|}{9.87} \\
\hline & \multicolumn{2}{|c|}{13.81} & \multicolumn{2}{|c|}{2,61} & \multicolumn{2}{|c|}{6.98} \\
\hline
\end{tabular}

${ }^{1}$ Non $=$ Non-inoculated 
TABLE 4. Soybean grain yield $\left(\mathrm{kg} \mathrm{ha}^{-1}\right)$ obtained at different planting dates following inoculation with Bradyrhizobia in northern Uganda

\begin{tabular}{|c|c|c|c|c|c|c|}
\hline \multirow[b]{2}{*}{ Planting dates } & \multicolumn{2}{|c|}{ Season $2010 B$} & \multicolumn{2}{|c|}{ Season 2011A } & \multicolumn{2}{|c|}{ Season 2011B } \\
\hline & Non $^{1}$ & Inoculated & Non & Inoculated & Non & Inoculated \\
\hline 0 & 1222 & 1278 & 1641 & 1647 & 1424 & 1454 \\
\hline 10 & 875 & 965 & 1439 & 1452 & 1197 & 1227 \\
\hline 20 & 458 & 0.507 & 1.326 & 1335 & 485 & 500 \\
\hline 30 & 285 & 312 & 929 & 947 & 0 & 0 \\
\hline \multirow{2}{*}{$\operatorname{LSD}_{(0.05)} \begin{array}{l}\text { Planting date } \\
\text { Inoculation }\end{array}$} & \multicolumn{2}{|c|}{135.3} & \multicolumn{2}{|c|}{66.9} & \multicolumn{2}{|c|}{45.8} \\
\hline & \multicolumn{2}{|c|}{95.7} & \multicolumn{2}{|c|}{47.3} & \multicolumn{2}{|c|}{32.4} \\
\hline
\end{tabular}

${ }^{1}$ Non $=$ Non-inoculated

TABLE 5. Decrease in soybean yield (\%) at different planting dates from onset of rain season obtained from an experiment in Lira, northern Uganda

\begin{tabular}{|c|c|c|c|c|c|c|}
\hline \multirow[t]{2}{*}{ Planting dates } & \multicolumn{2}{|c|}{ Season 2010B } & \multicolumn{2}{|c|}{ Season 2011A } & \multicolumn{2}{|c|}{ Season 2011B } \\
\hline & Non $^{1}$ & Inoculated & Non & Inoculated & Non & Inoculated \\
\hline 0 & - & - & - & - & - & \\
\hline 10 & $28.4 \pm 5.5$ & $24.5 \pm 5.1$ & $12.3 \pm 2.5$ & $11.8 \pm 3.9$ & $15.9 \pm 1.4$ & $15.6 \pm 2.4$ \\
\hline 20 & $62.5 \pm 7.9$ & $60.3 \pm 4.9$ & $19.2 \pm 3.3$ & $18.9 \pm 2.6$ & $65.9 \pm 2.2$ & $65.5 \pm 3.9$ \\
\hline 30 & $76.7+9.9$ & $75.6 \pm 7.3$ & $43.4 \underline{ \pm} 5.7$ & $42.5 \pm 3.9$ & $100.0 \pm 0.0$ & $100.0 \pm 0.0$ \\
\hline
\end{tabular}

$\pm=$ Standard deviation

4).Yield loss following delayed planting date was attributed to the cessation of the rains at the pod filling stage (Fig. 1). The practice of early planting is always recommended for all short duration (annual) crops (Matsuo et al., 2016) and this study has shown that planting soybean beyond 20 days after onset of rains leads to poor or total yield loss, irrespective of inoculation (Table 4). A simulation study by Eulenstein et al. (2016) predicted a decrease in soybean yield following climate change between 2011 and 2040, irrespective of the varieties used in the study. The present study is consistent with this prediction and further shows that the benefits of biological nitrogen fixation reduce when soybean is planted after 20 days from the onset of rainy season. This may have a future implication on legume inoculation and practices for increasing biological nitrogen fixation and grain yield in an effort to circumvent the effect of low soil fertility in SSA, thus increasing costs of soybean production.

Bradyrhizobia strain community. The presence of Bradyrhizobia strains in both rhizosphere and nodule, followed neither planting date nor inoculation. This indicates that the rhizobial population diversity in soils is a resultant of interactions among the bacteria, host plant and environmental factors as earlier reported by Zhang et al. (2011) and Yan et al. (2014). Rhizosphere had high abundance of Bradyrhizobia species, which was fairly stable between seasons (Fig. 3). There were 8 and 12 clusters observed from soil and nodules at $5 \%$ dissimilarity, respectively, irrespective of the season. 

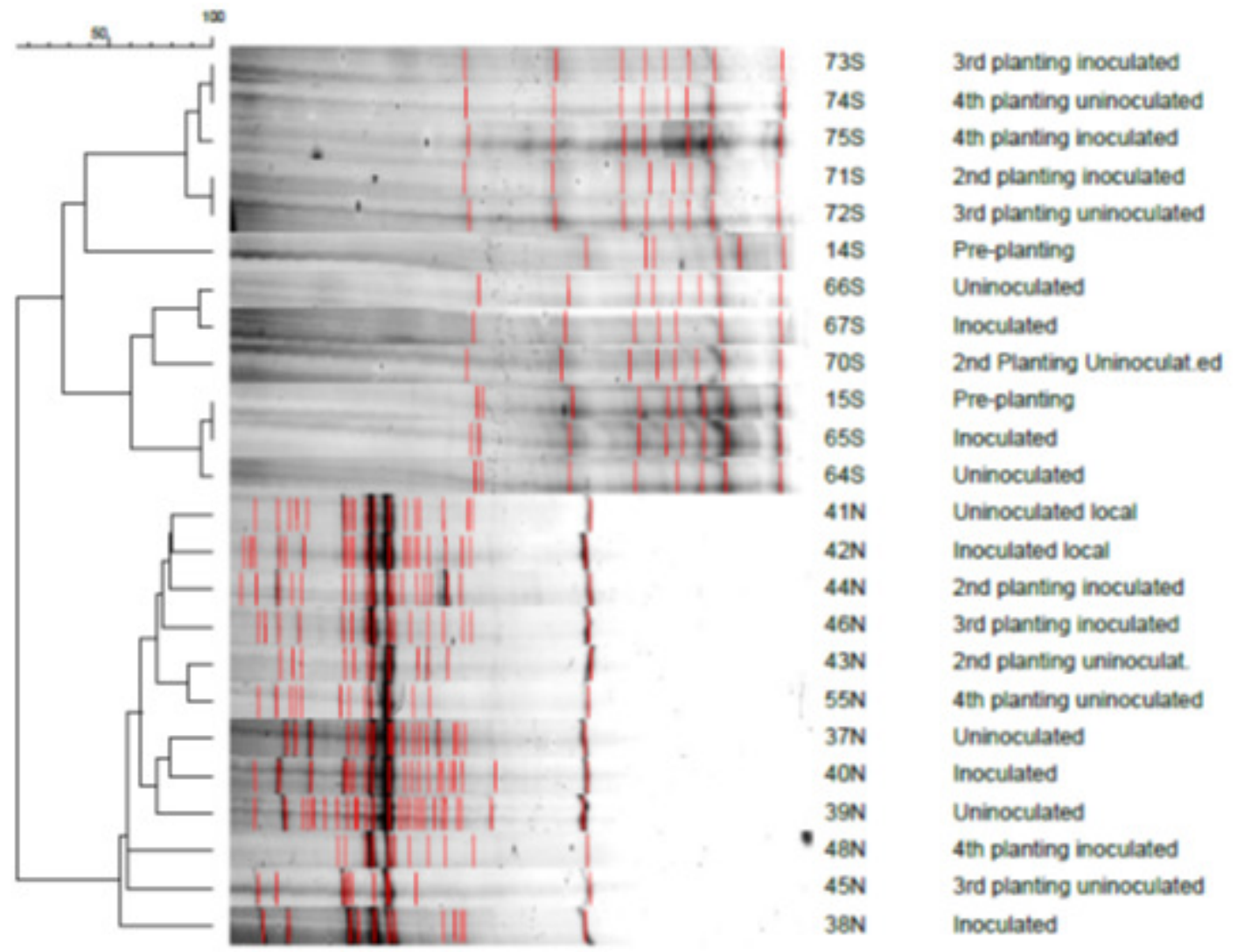

Figure 3. Dendogram showing SSCP Profile clusters of bacterial communities in rhizosphere soils (S) and within nodules of soybean $(\mathrm{N})$ observed during an experiment to leverage biological nitrogen fixation by planting date.

However, the nodules hosted an even higher abundance of alphaproteobacteria, as shown by more independent bands with the clusters of nodule extracted DNA irrespective of inoculation (Fig. 3). This could be attributed to a more conducive environment within the nodule than the soil, such as, plenty of soluble sugars, sufficient moisture and protection against hostile edaphic condition (Munévar and Wollum, 1981; Woomer et al., 1988; Hungria and Franco, 1993; Vlassak et al., 2010). Secondly, the nodules contained the native and introduced Bradyrhizobia strains. The Bradyrhizobia strain diversity in the nodule (Fig. 3), may decrease biological nitrogen fixation because of competition among strains within the nodules for nutrients and their differences in ability fix nitrogen. This can be alleviated by selection of superior strain to $B$. japonium USDA 110 from among the native Bradyrhizobia strains that is more adapted to native condition for inoculum formulation. Bradyrhizobia diversity in the nodule did not differ with planting date and cannot be attributed to difference in planting dates.

Sequencing of bands from SSCP profiles, identified Bradyrhizobia strains corresponding to $B$. japonicum, $B$. japonicum (USDA 6), $B$. elkanii, B. liaoningense and B. canariense, B. yuanmingese, Bradyrhizobia spp. and unknown Rhizobia spp. from soil (Fig. 3). On the other hand, the nodules had B. japonicum, B. japonicum (USDA 6), B. elkanii, B. liaoningense and $B$. yuanmingense. The presence of different strains in nodules, despite its inoculation with B. japonicum (USDA 110); and the formation of nodules without inoculation indicates presence of native 
effective strains. It can also be attributed to promiscuity of the soybean variety (Sanginga et al., 2002). In Nigeria, the native and elite Bradyrhizobia in inoculants were reported to competitively form nodules on soybean (Okogun et al., 2003). However, some of the bands from the nodules did not contain any known Bradyrhizobia spp., but belonged to other species of $\alpha$-proteobacteria. This is an indication that during nodule formation, other bacteria strains enter the nodule, but their effect on biological nitrogen fixation was not evaluated in the present study.

Five out of the eight known Bradyrhizobium spp. were identified from the soil and nodules in this study. These were Bradyrhizobium japonicum, Bradyrhizobium japonicum (USDA 6), Bradyrhizobiu melkanii, Bradyrhizobium liaoningense, Bradyrhizobium canariense and Bradyrhizobium yuanmingense. Strains Bradyrhizobium canarienses and Bradyrhizobium yuanmingense are not known to form nodules on soybean (Vinuesa et al., 2005). These might be biovars of the two species that have developed the ability to nodulate soybean.

Earlier studies reported Bradyrhizobium liaoningensein alkaline soils (Appunu et al., 2008), and Bradyrhizobium japonicum and Bradyrhizobium elkaniiin acid soils (Shiro et al., 2013); but the present study has found Bradyrhizobium liaoningense in acidic soils (Table 1). Soybean and groundnuts were the common crops grown in the study area and these form nodules with Bradyrhizobia strains (Abaidoo et al., 2000). The presence of Bradyrhizobia strains in the nodule not introduced through inoculant reduced the effectiveness on inoculation leading to erratic response as earlier reported (Mpepereki et al., 2000), which is not related to planting date.

\section{CONCLUSION}

Within the climate change affected onset of rainy seasons in northern Uganda, soybean should be planted within 10 days from the onset of rains to leverage on attainable nodulation and attendant grain yield. Planting date does not affect diversity of Bradyrhizobia strains in the soil and nodulation. However, planting later than 20 days from the onset of rains season reduces the number and percentage of effective nodules irrespective of Bradyrhizobia inoculation thus lowering potential of biological nitrogen fixation.

\section{ACKNOWLEDGEMENT}

We are grateful to USAID/LEAD project Number USIAD/LEAD 070 "Adapting to climate change through integrated nutrient and water management" that funded this study through Sustainable Livelihoods International.

\section{REFERENCES}

Abaidoo, R.C., Keyser, H.H., Singleton, P.W. and Borthakur, R. 2000. Bradyrhizobium spp. (TGx) isolates nodulating the new soybean cultivars in Africa are diverse and distinct from Bradyrhizobia that nodulate North American soybeans. International Journal of Systematic and Evolutionary Microbiology 50:225-234.

Appunu, C., N'Zoue, A. and Laguerre, G. 2008. Genetic diversity of native Bradyrhizobia isolated from soybeans (Glycine $\max$ L.) in different agriculturalecological-climatic regions of India. Applied and Environmental Microbiology 74:5991-5996. http://dx.doi.org/10.1128/ AEM.01320-08.

Dohrmann, A. and Tebbe, C.C. 2005. Effect of elevated tropospheric ozone on the structure of bacterial communities inhabiting the rhizosphere of herbaceous plants native to Germany. Applied Environmental Microbiology 71:77507758.

Eulenstein, F., Lana, M., Schlindwein, S., Sheudzhen, A., Tauschke, M., Behrend, A., Guevara, E. and Meira, S. 2016. Trends of soybean yield under climate change 
scenarios. Horticulturae (2017) 3(10):1-5. doi:10.3390/horticulturae3010010.

Food and Agriculture Organisation (FAO). 1984. Legume inoculants and their use. A pocket manual jointly prepared by Nitrogen Fixation for Tropical Agricultural Legumes (NifTAL) Project, USA and FAO. Burton, J. (Ed.). Land and water development division, FAO, Rome, Italy. 96pp.

Fu, T., Ha, B. and Ko, J. 2016. Simulation of $\mathrm{CO}_{2}$ enrichment and climate change impacts on soybean production. International Agrophysics 30: 25 - 37.

Giller, K.E. 2001. Nitrogen Fixation in Tropical Cropping Systems, $2^{\text {nd }}$ Ed. $C A B$ International, Wallingford, UK. 423pp.

Gyogluu, C., Boahen, S.K. and Dakora, F.D. 2016. Response of promiscuousnodulating soybean (Glycine max L. Merr.) genotypes to Bradyrhizobium inoculation at three field sites in Mozambique. Symbiosis 69: 81-88. http://dx.doi.org/ 10.1007/s13199-015-0376-5.

Hardarson, G. and Atkins, C. 2003. Optimising biological $\mathrm{N}_{2}$ fixation by legumes in farming systems. Plant and Soil 252:41-54.

Herridge, D.F., Peoples, M.B. and Boddey, R.M. 2008. Global inputs of biological nitrogen fixation in agricultural systems. Plant Soil 311:1-18.

Hu, Q., Yang, N., Pan, F., Pan, X., Wnag, X. and Yang, P. 2017. Adjusting sowing dates improved potato adaptation to climate change in semiarid region, China. Sustainability (2017), 9: 615. doi:10.3390/ su9040615.

Hungria, M. and Franco, A.A. 1993. Effect of high temperature on nodulation and nitrogen fixation by Phaseolus vulgaris L. Plant and Soil 149: 95-122.

Keyser, H.H. and Li, F. 1992. Potential for increasing biological nitrogen fixation in Soybean. Plant and Soil 141:119 -135.

Kumar, V., Rawat, A.K. and Rao, D.L.N. 2017. Population ecology of soybean-rhizobia in diverse crop rotation in central India. Agriculture, Ecosystem and Environment 240:261-268.
Mapfumo, P., Adjei-Nsiah, S., Mtambanengwe, F., Chikowo, R. and Giller, K.E. 2013. Participatory action research (PAR) as am entry point for supporting climate change adaption by smallholder farmers in Africa. Environmental Development 5:6-22.

Matsuo, N., Fukami, K. and Tsuchiya, S. 2016. Effects of early planting and cultivars on the yield and agronomic traits of soybeans grown in south western Japan. Plant Production Science 19(3): 370-380. https://doi.org/10.1080/1343943X.2016. 1155417.

Mpepereki, S., Javaheri, F., Davis, P. and Giller, K.E. 2000. Soybeans and sustainable agriculture. Field Crops Research 65: 137149. http://dx.doi.org/10.1016/S0378$\underline{4290}$.

Munévar, F. and Wollum, A.G. 1981. Effect of high soil temperature and rhizobium strain on nodulation, nitrogen fixation and growth of Soybean. Soil Science Society of America Journal 45:1113-1120.

Okalebo, J.R., Gathua, K.W. and Woomer, P.L. 2002. Laboratory methods of soil and plant analysis: a working manual. $2^{\text {nd }}$ Ed. Tropical Soil Biology and Fertility Programme, Nairobi, Kenya. 88pp.

Okogun, J.A. and Sanginga, N. 2003. Can introduced and indigenous rhizobial strains compete for nodule formation by promiscuous soybean in the moist savannah agroecological zone of Nigeria? Biological Fertility of Soils 38:26 -31.

Sainz, M., Calvo-Begueria, L., Pérez-Rontomé, C., Wienkoop, S., Abián, J., Staudinger, C., Bartesaghi, S., Radi, R. and Becana, M.2016. Leghemoglobin is nitrated in functional legume nodules in a tyrosine residue within the heme cavity by a nitrite/ peroxide-dependent mechanism. Plant Journal 81(5):723 - 735. http://doi:10. 1111/tpj.12762

Sanginga, N., Okogun, J., Vanlauwe, B. and Dashiell, K. 2002. The contribution of nitrogen by promiscuous soybean to maize based cropping of the moist Savanna Nigeria. Plant and Soil 241: 223-231. 
Sanginga, N., Abaidoo, R., Dashiell, K., Carsky, R.J. and Okogun, A. 1996. Persistence and effectiveness of rhizobia nodulating promiscuous soybeans in moist savanna zones of Nigeria. Applied Soil Ecology 3:215-224. http://dx.doi.org/ 10.1016/0929-1393.

Smalla, K., Oros-Sichler, M., Milling, A., Heuer, H., Baumgarte, S., Becker, R., Neuber, G., Kropf, S., Ulrich, A. and Tebbe, C.C. 2007. Bacterial diversity of soils assessed by DGGE, T-RFLP and SSCP fingerprints of PCR-amplified 16S rRNA gene fragments: Do the different methods provide similar results? Journal of Microbiological Methods 69:470-479. doi:10.1016/j.mimet.2007.02.014

Thomas, R., Van, B., Skip, J. and Schlesinger, W. 2006. Climate change and symbiotic nitrogen fixation in agroecosystems. In: Newton, P.C.D., Carran, R.A., Edwards, G.R. and Niklaus, P.A. (Eds.). Agroecosystems in a changing climate. Published by Taylor and Francis. DOI:10.1201/9781420003826.ch4. pp. 85 $-116$.

Thuita, M., Pypers, P., Herrmann, L., Okalebo, R.J., Othieno, C., Muema, E. and Lesueur, D. 2012. Commercial rhizobial inoculants significantly enhance growth and nitrogen fixation of a promiscuous soybean variety in Kenyan soils. Biology and Fertility of Soils 48: 87-96. http://dx.doi.org/10.1007/ s00374-011-0611-Z

Vadez, V., Berger, J.D., Warkentin, T., Asseng, S., Ratnakumar, P., Rao, K.P.C., Guar, P.M., Munier, J.N., Larmure, A., Voisin, A.S., Sharma, H.C., Pande, S., Sharma, M., Krishnamurthy, L. and Zaman, M.A. 2012. Adaption of grain legumes to climate change: Review. Agronomy of Sustainable Development 32(1):31 - 44. van Heerwaarden, J., Baijukya, F., KyeiBoahen, S., Adjei-Nsiahd, S., Ebanyat, P., Kamai, N., Wolde-meskel, E., Kanampiu, F., Vanlauwe B. and Giller, K. 2018. Soyabean response to rhizobium inoculation across sub-Saharan Africa: Patterns of variation and the role of promiscuity. Agriculture, Ecosystems and Environment 261:211 -218. https://doi.org/ 10.1016/j.agee.2017.08.016.

Vlassak, K.M., Vanderleyden, J. and Graham, P.H. 2010. Factors influencing nodule occupancy by inoculant rhizobia. Journal of Critical Review in Plant Sciences 16:163 - 229. https://doi.org/10.1080/073526897 09701948.

Vinuesa, P., León-Barrios, M., Silva, C., Willems, A., Jarabo-Lorenzo, A., PérezGaldona, R., Werner, D. and MatínezRomero, E. 2005. Bradyrhizobium canariense sp. nov. an acid tolerant endosymbiont that nodulates endemic genistoid legumes (Papilionoideae: Genisteae) from the Canary Islands, along with Bradyrhizobium japonicumbv. genistearum, Bradyrhizobium genospecies alpha and Bradyrhizobium genospecies beta. International Journal of Systematic and Evolutionary Microbiology 55:569-575.

Yan, J., Zeng, H.X., J.J., Li, Y., Tao, W.E., Hong, X.Z. and Feng, C.W. 2014. Abundance and diversity of soybeannodulating rhizobia in black soil are impacted by land use and crop management. Applied and Environmental Microbiology 80:5394-5402.

Zhang, Y.M., Li, Y., Chen, W.F. Jr., Wang, E.T., Tian, C.F., Li, Q.Q., Zhang, Y.Z., Sui, X.H. and Chen, W.X. 2011. Biodiversity and biogeography of rhizobia associated with soybean plants grown in the north china plain. Applied and Environmental Microbiology 77:6331-6342. 